\title{
How can juxtaglomerular renin-producing cells support the integrity of glomerular endothelial cells?
}

\author{
Armin Kurtz ${ }^{1}$ (D) \\ Received: 30 July 2019 / Revised: 30 July 2019 / Accepted: 1 August 2019 / Published online: 8 August 2019 \\ (C) Springer-Verlag GmbH Germany, part of Springer Nature 2019
}

Over the last years, findings have been accumulated to indicate that renin-producing cells and their "silent" precursors show a striking degree of plasticity not only to regulate renin. Renin-secreting cells of the kidney, which are typically located in a juxtaglomerular position at the entrance of afferent arterioles into their glomeruli, are the key regulators of the renin-angiotensin-aldosterone system. From their origin, they are pericyte-related cells [9] which descend from the FoxD1positive stroma progenitor compartment of the kidney [2]. It is well established that the number of renin-secreting cells can increase by hyperplasia and also by reversible metaplastic transformation of "silent" renin-producing cells into active renin producers and vice versa [4]. The common genomic signature of "silent" and of active renin-producing cells has recently been unraveled [6]. A key step for renin expression is activation of the cyclic AMP signaling cascade [4].

Synthesis and secretion also serve other functions. Thus, it has been shown that genetic activation of the hypoxia signaling pathway in renin cells suppresses renin expression and induces erythropoietin expression [3]. Moreover, renin cells or their "silent" precursors have been found to serve glomerular function, for instance by repopulating the mesangium after mesangial cell injury [8]. Further evidence in this context has been reported that renin cells might also act as precursors for podocytes after podocyte damage [1]. Although renin cells cannot repopulate damaged glomerular endothelial cells [7], they appear to exert a protective effect on endothelial cells. The article by Steglich and coworkers entitled "Renin cells with defective Gs $\alpha / \mathrm{cAMP}$-signaling contribute to renal endothelial damage" as published in this issue of Pflügers Archiv

This article is a commentary to the original article https://doi.org/10.1007/ s00424-019-02298-9

Armin Kurtz

armin.kurtz@vkl.uni-regensburg.de

1 Physiologisches Institut, Universität Regensburg, 93053 Regensburg, Germany now confirms and extends previous findings that renin cells have also influence on the integrity of the glomerular endothelium [5]. The authors report that continuous disruption of cAMP signaling by renin cell-specific deletion of the Gs $\alpha$ protein downregulated renin expression as expected, but in addition also led to endothelial damage of glomerular capillaries as indicated by the change of morphological and genetic markers. In reverse, this finding could indicate that intact cAMP signaling in juxtaglomerular cells is required for normal glomerular endothelial function. The authors present data that indicate that a loss of renin cells and the concomitant decrease in renin production induced by the expression of diphtheria toxin in renin cells per se exert no apparent detrimental effect on endothelial cells. They also found that deletion of Gs $\alpha$ protein in renin cells did not destroy the cells but instead caused a phenotype switch to a renin-negative and fibroblast-like cell. The authors suggest that the new profibrotic cell phenotype directly or indirectly causes endothelial damage. Notably, genetic induction of the hypoxia signaling pathway causes a similar profibrotic phenotype shift of renin cells as does deletion of Gs $\alpha$ protein [3]. It will be tempting to investigate therefore if phenotype changes of renin cells into fibroblast-like cells induced by maneuvers other than interruption of cAMP signaling will also cause endothelial damage or if the effect is causally related to insufficient cAMP signaling in the cells.

In summary, this paper provides new insights into a possible role of renin-producing cells beyond renin formation and thus adds a further piece of evidence to the existing knowledge about the functional plasticity of renin-producing cells.

\section{References}

1. Eng DG, Kaverina NV, Schneider RRS, Freedman BS, Gross KW, Miner JH, Pippin JW, Shankland SJ (2018) Detection of renin lineage cell transdifferentiation to podocytes in the kidney glomerulus with dual lineage tracing. Kidney Int 93:1240-1246. https://doi.org/ 10.1016/j.kint.2018.01.014 
2. Gomez RA, Sequeira-Lopez MLS (2016) Novel functions of renin precursors in homeostasis and disease. Physiology 31:25-33. https:// doi.org/10.1152/physiol.00039.2015

3. Kurt B, Paliege A, Willam C, Schwarzensteiner I, Schucht K, Neymeyer H, Sequeira-Lopez MLS, Bachmann S, Gomez RA, Eckardt K-U, Kurtz A (2013) Deletion of von Hippel-Lindau protein converts renin-producing cells into erythropoietin-producing cells. J Am Soc Nephrol JASN 24:433-444. https://doi.org/10.1681/ASN. 2012080791

4. Kurtz A (2011) Renin release: sites, mechanisms, and control. Annu Rev Physiol 73:377-399. https://doi.org/10.1146/annurev-physiol012110-142238

5. Lachmann P, Hickmann L, Steglich A, Al-Mekhlafi M, Gerlach M, Jetschin N, Jahn S, Hamann B, Wnuk M, Madsen K, Djonov V, Chen M, Weinstein LS, Hohenstein B, Hugo CPM, Todorov VT (2017) Interference with Gs $\alpha$-coupled receptor signaling in reninproducing cells leads to renal endothelial damage. J Am Soc Nephrol JASN 28:3479-3489. https://doi.org/10.1681/ASN. 2017020173

6. Martinez MF, Medrano S, Brown EA, Tufan T, Shang S, Bertoncello N, Guessoum O, Adli M, Belyea BC, Sequeira-Lopez MLS, Gomez
RA (2018) Super-enhancers maintain renin-expressing cell identity and memory to preserve multi-system homeostasis. J Clin Invest 128:4787-4803. https://doi.org/10.1172/JCI121361

7. Ruhnke L, Sradnick J, Al-Mekhlafi M, Gerlach M, Gembardt F, Hohenstein B, Todorov VT, Hugo C (2018) Progenitor Renin Lineage Cells are not involved in the regeneration of glomerular endothelial cells during experimental renal thrombotic microangiopathy. PLoS One 13:e0196752. https://doi.org/10.1371/journal.pone. 0196752

8. Starke C, Betz H, Hickmann L, Lachmann P, Neubauer B, Kopp JB, Sequeira-Lopez MLS, Gomez RA, Hohenstein B, Todorov VT, Hugo CPM (2015) Renin lineage cells repopulate the glomerular mesangium after injury. J Am Soc Nephrol JASN 26:48-54. https://doi.org/10.1681/ASN.2014030265

9. Stefanska A, Kenyon C, Christian HC, Buckley C, Shaw I, Mullins JJ, Péault B (2016) Human kidney pericytes produce renin. Kidney Int 90:1251-1261. https://doi.org/10.1016/j.kint.2016.07.035

Publisher's note Springer Nature remains neutral with regard to jurisdictional claims in published maps and institutional affiliations. 